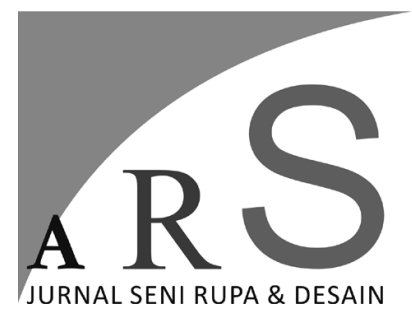

Volume 23 Nomor 1 Januari - Maret 2020

\title{
BUDAYA VISUAL DALAM TRADISI SIKLUS KEHIDUPAN MASYARAKAT JAWA DI TULUNGAGUNG
}

\section{Fathoni Setiawan \& Warih Handayaningrum}

Program Studi S2 Pendidikan Seni Budaya, Program Pascasarjana, Universitas Negeri Surabaya

Jl. Rektorat Unesa, Lidah Wetan, Kec. Lakarsantri, Kota Surabaya, Jawa Timur 60213

Telepon: 089679224860, E-mail: setiawanfathoni@gmail.com

\begin{abstract}
ABSTRAK
Penelitian ini berupaya untuk mendeskripsikan berbagai budaya visual yang masih berlaku dan digunakan oleh masyarakat Jawa di Tulungagung. Masyarakat Tulungagung dinilai masih kental akan tradisi Jawanya, terbukti dengan masih lestarinya berbagai tradisi salah satunya yang berkaitan dengan siklus hidup. Melalui tulisan penelitian ini diharapkan akan di dapatkan pemahaman tentang budaya visual yang sering digunakan, di mana biasanya masyarakat mengambil sebuah kebudayaan secara 'taken for granted' tanpa mengetahui tentang budaya yang dijalankannya. Dengan dipahaminya budaya visual yang ada, maka kemungkinan untuk pengembangan dan pelestarian kebudayaan yang ada akan semakin terbuka peluangnya dan terjaga esensi dari kebudayaan itu sendiri. Untuk kedepannya ketika pemahaman tentang budaya visual tradisi mulai ditumbuhkan, diharapkan hal tersebut dapat menjadi aset atau modal kreatif dalam mengembangkan budaya visual kebaruan tanpa meninggalkan esensi budaya visual tradisi yang merupakan identitas bangsa.
\end{abstract}

Kata kunci: budaya visual, siklus hidup, Tulungagung

\begin{abstract}
This study asks to describe the various cultures that are still valid and used by the Javanese community in Tulungagung. The Tulungagung community discusses the Javanese tradition is still thick, as evidenced by the still preserving of various traditions, one of which is related to life competition. It is hoped that through this research writing, it will be obtained about understanding the visual culture that is often used, where people usually take the culture that is taken for granted without knowing about the culture that it runs. With the understanding of the existing visual culture, the expenditure for the development and preservation of agriculture will increasingly open up opportunities and save the essence of cultivation itself. In the future, a compilation of visual traditions will begin to grow, hopefully it can become an asset or creative capital in developing a new culture without opening the essence of visual culture that shapes national identity.
\end{abstract}

Keywords: visual culture, life cycle, Tulungagung 


\section{Pendahuluan}

Jawa sebagai salah satu bagian dari Indonesia dan Nusantara di masa lalu, menjadikan Jawa juga merupakan tempat dimana bertemunya berbagai macam kebudayaan sehingga memungkinkan terjadinya kemungkinan percampuran dua budaya atau lebih melalui proses difusi maupun akulturasi. Perlu diperjelas bahwa terdapat perbedaan pengertian ketika berbicara tentang 'Jawa'. Jawa sebagai suatu wilayah maka mencangkup sebuah wilayah pulau yang terbentang dari Banyuwangi di bagian paling timur dan wilayah Banten sebagai ujung baratnya. Jawa juga dapat diartikan sebagai suatu etnis atau suku. Suku Jawa secara umum diketahui hanya melingkup mereka yang mayoritas berasal dari Jawa Timur dan Jawa Tengah, sedangkan sisanya merupakan suku lain (suku Sunda, Betawi, dan lain sebagainya). Pada masyarakat Jawa ini telah tumbuh berbagai nilai hidup maupun kebudayaan yang berisi mengenai konsep-konsep yang dapat digunakan sebagai pedoman hidup. Konsep ini yang kemudian membuat pemakainya disebut sebagai orang Jawa. Koentjaraningrat (dalam Dimyati, 2003) menyebutkan bahwa Orang Jawa adalah kelompok etnik masyarakat yang mempunyai kebudayaan dan nilai maupun kebiasaan mengenai sesuatu, yaitu kebudayaan Jawa. Jadi dalam tulisan ini, ketika disebutkan istilah Jawa atau orang Jawa, maka akan lebih mengacu kepada masyarakat yang menjalankan tradisi dan kebudayaan Jawa, khususnya Tulungagung.

Kebudayaan Jawa secara luas memiliki subsub seperti budaya lisan dan budaya visual. Menurut Morgan (dalam Sachari, 2007) yang disebut budaya visual adalah hasil dari proses kebudayaan yang di dalam hasil tersebut terdapat tujuan untuk menjelaskan beragam fenomena dalam bentuk visual yang tercipta akibat dari cara berfikir dan 'mengimajinasi' secara sosial. Menurut Morgan pula dalam proses menciptakan suatu budaya visual maka perlu dibuat sebuah 'imaji', yang mana 'imaji' ini dibuat agar dipergunakan sebagai media untuk 'membentuk' kehidupan manusia. Dalam budaya visual 'imaji' biasanya dipandang sebagai wujud dari 'nilai praktis'. Maksudnya imaji dilihat dari bagaimana penggunaannya dalam konteks budaya visual oleh berbagai pihak seperti, masyarakat secara umum, seniman, budayawan, dan lain sebagainya. Pihak-pihak diatas pula yang diawal memiliki peran dalam memberi makna sehingga 'imaji' baru tercipta.

Di kebudayaan Jawa, budaya visual memiliki tempat khusus di dalam tradisi maupun kehidupan sehari-hari. Budaya visual masyarakat Jawa dapat dikatakan mempunyai cakupan yang cukup luas, antara lain meliputi, benda pakai (ageman), tosan aji (pusaka), benda ritual, hingga seni arsitektur. Secara lebih luasyang dimaksud dengan budaya visual bisa dalam bentuk apapun yang dapat dinikmati dengan indra penglihat dan peraba, dimana dalam wujud tersebut terdapat ide-ide, gagasan, maupun nilai yang ditanamkan. Namun semakin hari penerapan budaya visual Jawa baik secara fungsional maupun sebagai identitas semakin pudar dan hilang arah. Hal ini tak lain salah satunya akibat minimnya pengetahuan tentang budaya visual masyarakat Jawa yang kian hari kian tertindih oleh berbagai budaya visual baru yang bermunculan.

Proses globalisasi yang telah beberapa dekade bergulir yang menyebabkan terjadinya pertukaran informasi secara cepat dan sulit dikendalikan, melampaui batasan ruang dan waktu menyebabkan kacaunya pengetahuan yang dimiliki manusia. Manusia sebagai sebuah individu menjadi subjek yang lebih bebas menentukan selera, lebih bebas memilih mana yang ingin dilihat dan ingin diketahui. Akan tetapi di dunia dengan perkembangan yang demikian, manusia juga sekaligus menjadi objek yang mudah 'dikondisikan'. Maksudnya manusia sekaligus berpeluang menjadi subjek pasif yang hanya menerima apa yang 'disuguhkan' kepada mereka. Hal ini berlanjut ketika hal berbau kebudayaan lokal seberti budaya visual masyarakat Jawa hanya menjadi bagian yang semakin kecil jika dibandingkan dengan budaya visual dunia skala global, sehingga akhirnya kurang mendapat perhatian. Dengan demikian identitas budaya visual masyarakat Jawa pun pada akhirnya akan kian memudar, dan pengetahuan tentang budaya visual itu sendiri akan terkikis dan hilang.

Permasalahan yang demikian menambah pelik kebiasaan warisan dari masa lalu untuk 'taking something for granted' yang juga dilakukan masyarakat Jawa termasuk masyarakat di Tulungagung. 
Kebiasaan melakukan sesuatu tanpa mengetahui esensi apa yang dilakukan dalam jangka panjang buruk, seperti mudah digantikannya sebuah kebudayaan. Contoh masalah lain adalah ketika kurangnya pengetahuan tentang esensi sebuah kebudayaan maka ketika dilakukan pengembangan dalam upaya pelestarian atau revitalisasi suatu kebudayaan maka esensi yang seharusnya dijaga malah dikesampingkan. Contohnya dapat dilihat dari berbagai komodifikasi budaya yang tengah ramai terjadi, yang semata untuk menambah nilai hiburan, mementingkan fungsi ekonomi praktis, dan mengesampingkan esensi dari kebudayaan yang 'dijual' tersebut.

Serupa dengan apa yang dijelaskan di atas, kebudayaan visual dalam masyarakat Tulungagung juga mengalami masalah yang sama. Masyarakat di Tulungagung yang juga kurang mengetahui asal dan tujuan budaya visual yang sebelumnya ada, kemudian menderita 'gagap' informasi dampak dari 'boom data' yang terjadi maka seakan menjadi pihak yang mengalir menerima begitu saja perubahan yang terjadi dan meninggalkan budaya yang semula menjadi identitas mereka, yang seharusnya mereka jaga. Memang hal ini tidak terjadi secara menyeluruh atau total kepada mayarakat di Tulungagung, namun apabila tidak dilakukan upaya semacam penanggulangan maka hal ini akan berlanjut dan semakin parah, berdampak hilangnya budaya identitas masyarakat Tulungagung. Bahkan dalam skala lebih luas hilangnya budaya identitas masyrakat Jawa seperti ketika Batik pernah hampir d akuisisi sebagai kebudayaan negara Malaysia pada kisaran tahun 2008.

Maka dalam upaya menanggulangi permasalahan terkikisnya minat akibat kurangnya pengetahuan tentang budaya visual masyarakat Jawa, penulis berupaya menyuguhkan tulisan yang diharapkan mampu menambahkan wawasan tentang budaya visual masyarakat Jawa itu sendiri khususnya yang berada di Tulungagung. Secara lebih spesifik penulis hanya membatasi budaya visual yang ada pada ritual yang berkaitan dengan siklus kehidupan manusia yang dilakukan oleh masyarakat Tulungagung. Dalam tulisan ini pula akan disajikan berbagai contoh upaya yang dilakukan dalam upaya prevensi terkikis dan hilangnya budaya visual masyarakat Jawa oleh masyarakat. Karena mau tidak mau masyarakatlah yang berhubungan langsung dengan kebudayan itu sendiri.

\section{Metode dan Tujuan Penelitian}

Penelitian ini merupakan penelitian berbentuk kualitatif yang dijabarkan secara deskriptif. Penelitian ini dilakukan dengan berdasar pada sumber-sumber primer seperti observasi dan wawancara dan juga sekunder seperti buku, jurnal, artikel, dan berbagai konten baik yang berbentuk fisik atau cetak, maupun yang berbentuk digital. Sumber-sumber yang digunakan sebelumnya dilakukan pemilihan berdasarkan relevansinya dengan penelitian yang dilakukan. Dipilihya sumber primer karena objek yang diteliti masih cukup lestari di sekitar penulis. Sedangkan sumber sekunder sebagai sumber alternatif penelitian karena telah cukup banyak tersedianya sumbersumber yang diperlukan sebagai bahan penelitian untuk melangkapi dan menambah keabsahan data yang diperoleh dari sumber data primer. Adapun teori yang akan digunakan sebagai instrumen atau alat untuk membedah data yang ditemukan adalah teori semiotika.

Penelitian ini berusaha menjelaskan beragam budaya visual yang ada dan masih digunakan dalam tradisi masyarakat Jawa khusunya di daerah Tulungagung, agar dapat menambah atau pun memunculkan kembali wawasan bagi para pembaca. Bagi pembaca yang berlatarbelakang seni diharapkan ketika berkarya dapat terstimulasi untuk menciptakan karya dengan nilai lebih sebagaimana dilakukan oleh seniman-seniman di masa lalu. Dalam tulisan diharapkan solusi tersebut dapat di gunakan oleh para pembaca, dan memberi kesadaran bahwa masalah tentang kebudayaan sesungguhnya dapat ditangani oleh individu, bagian terkecil dari masyarakat. Hal-hal tersebut menurut penulis dirasa penting mengingat budaya visual tradisi kian hari semakin tergeser oleh minimnya pengetahuan tentang budaya yang kita miliki ditambah dengan serangan budaya asing sehingga mungkin saja kelak budaya visual yang merupakan salah satu identitas penting bagi masyarakat penggunanya akan hilang dan punah. 


\section{Hasil dan Pembahasan}

\section{Budaya Visual sebagai Hasil Kreativitas}

Manusia Indonesia yang dulu dikenal sebagai Nusantara merupakan masyarakat yang telah terbukti memiliki tingkat kreativitas yang amat tinggi. Hal ini bukan semata isapan jempol, dapat dilihat dari berbagai peninggalan yang masih tersisa hingga hari ini. Wujud artefak hasil dari budaya visual menjadi salah satu yang paling mudah digunakan untuk melihat betapa agung kemampuan masyarakat Nusantara di masa lalu. Lihat candi-candi yang masih kokoh berdiri hingga hari ini, meskipun banyak yang telah terkikis waktu namun masih saja sangat menawan. Sebenarnya ketika dikaji lebih lanjut kemampuan tinggi dari masyarakat nusantara di masa lalu bukan hanya sebatas ketrampilan dan pengetahuan yang mereka miliki dalam hal penguasaan bahan. Terdapat kemampuan yang lebih menawan dari masyarakat ini. Kemampuan masyarakat di masa lalu untuk menanamkan ide, gagasan maupun kemampuan mengkodekan pesan ke dalam wujud visual atau benda. Hal ini yang menjadikan karya-karya yang dihasilkan oleh masyarakat di masa lalu memiliki nilai transenden di dalamnya, bukan sebatas sebagai pemenuhan kebutuhan. Dalam karya masyarakat di masa lalu akan dapat sering ditemui kompleksitas yang di dalamnya termuat gagasan, ide, hingga nilai filosifis yang amat dalam.

Budaya visual seperti yang dijelakan diatas, yang menurut Morgan (dalam Sachari, 2007) memiliki cakupan yang amat luas, yaitu setiap hal yang wujudnya dapat diindrai menggunakan indra penglihatan dan peraba. Budaya visual paling banyak diketahui dalam bentuk benda, dan bagi budaya visual yang merupakan peninggalan biasanya dikenal sebagai artefak. Dari artefak yang masih tersisa saat ini lah kita bisa menengok kembali betapa kaya dan luhurnya kebudayaan, termasuk budaya visual kita miliki di masa lalu. Ketika artefak seringkali diidentikkan sebagai hasil budaya yang telah lampau, namun demikian pada faktanya masih banyak wujud budaya visual yang masih eksis hingga hari ini. Misalnya yang ada di masyarakat Jawa, rumah adat atau arsitektur joglo, seni kriya meliputi kriya kayu, kriya logam, kriya keramik, hingga yang paling umum kriya tekstil. Meskipun semakin hari budaya visual yang ada semakin bergeser dan mulai kehilangan esensi yang dimilikinya di masa lalu, seperti yang terjadi pada kriya batik yang dulu selalu dianggap syarat akan makna, namun kini telah banyak bermunculan produk batik yang sekedar mengedepankan fungsi fesyen, dan komodifikasi atau ekonomi praktis.

Lantas benarkah budaya visual yang selama ini ada di tengah masyarakat Jawa dan khususnya masyarakat Tulungagung adalah hasil dari kreativitas? Untuk melihat kebenaran pernyataan ini salah satunya dapat digunakan teori kreativitas humanistik milik Abraham Maslow. Maslow dalam teorinya menggambarkan bahwa kreativitas akan mampu tercipta apabila kebutuhan-kebutuhan yang dimiliki oleh sesorang telah terpenuhi. Dalam hierarki yang diajukannya puncak dimana kreativitas ini akan muncul adalah ketika seseorang telah mencapai tahap aktualisasi diri. Untuk dapat mencapai tahapan ini haruslah dipenuhi terlebih dulu kebutuhankebutuhan yang lebih 'rendah'. Dalam Feist \& Feist (2010:280) disebutkan berbagai kebutuhan yang dimaksud seperti fisologis (makan, minum, adaptasi, dan lain sebagainya), rasa aman (kestabilan fisik, kemerdekaan, kebebasan), kasih sayang dan cinta (hubungan emosi antara sesama), penghargaan (ketenaran, rekognisi, dan lain sebagainya), ilmu pengetahuan (pengetahuan untuk hidup, pengetahuan manajemen, dan lain-lain), estetika (keindahan, keselarasan jiwa). Bila dilihat menggunakan hierarki Maslow ini, maka akan tampak bahwa secara empiris dulu masyarakat Jawa dahulu pernah terpenuhi kebutuhan-kebutuhannya, meskipun dalam kurun waktu yang lama telah mengalami siklus pasang dan surut, hingga hanya menyisakan budayanya (seperti batik) termasuk budaya visual sebagai wujud hasil aktualisasi diri, sebagai cara merepresentasikan diri, menciptakan identitasnya sendiri.

\section{Batik: dari Sebelum Lahir hingga Wafat}

Batik hingga hari ini telah menjadi salah satu budaya visual yang paling populer di kalangan masyarakat luas. Kepopuleran batik bahkan dewasa ini bukan hanya dalam lingkup regional, tetapi internasional. Batik saat ini telah menjadi sebuah identitas yang dikenali sebagai warisan budaya nusantara.

Batik secara etimologis dan terminologis dapat diartikan sebagai sebuah rangkaian kata yaitu dari 'mbat' dan 'tik'. 'Mbat' dalam istilah 
Jawa berasal dari kata ngembat (melempar berkali-kali), dan 'tik' berasal dari kata titik. Jadi apabila dirangkai diperoleh arti, 'melempar titik berkali-kali' (Astrini, 2018). Batik merupakan kain yang erat kaitannya dengan budaya masyarakat, yang tidak sebatas produksi, tetapi sebagai hasil budaya berisi nilainilai dari suatu masyarakat.

Hingga saat ini dapat ditemui ratusan bahkan ribuan macam motif batik hasil dari kreativitas para kreatornya. Menurut Lily Kasoem (dari laman kumparan.com, 2017), pendiri Yayasan Titian, ragam motif batik, corak, gaya hingga teknik yang telah tercipta hingga hari ini mungkin terjadi akibat adanya pergulatan yang intens dalam masyarakat Jawa. Beragam hal terkait batik tersebut kemudian terus berkembang selaras dengan kelengkapan berupa atribut makna filosofis di dalamnya. Motif batik yang sekian banyak tersebut tentu selalu menghadirkan berbagai ciri khas dan selalu tertanam nilai pula di dalamnya. Batik sebgai sebuah karya seni adalah penyaluran kreasi yang di dalamnya terdapat arti berkaitan dengan tradisi, kepercayaan serta sumber-sumber kehidupan yang berkembang di masyarakat (Handayani dan Emilda, 2018). Serupa dengan budaya visual lainnya yang berasal dari masa lalu batik tradisi hampir dapat dipastikan memiliki nilai transenden di dalamnya. Meskipun sejalan dengan perkembangan jaman batik terkadang hanya menurut pada fungsi komodifikasi atau ekonomi praktis, menuruti tuntutan pasar, sehingga tidak jarang tercipta motif baru yang mengesampingkan penanaman nilai di dalamnya.

Tulungagung dirunut berdasarkan sejarah sudah semenjak dahulu menjadi salah satu pusat dimana batik berkembang dengan pesat. Dikutip dari Perpustakaan Digital Budaya Indonesia (budaya-indonesia.org, diakses 3 Oktober 2019) setidaknya sudah terdapat 86 batik khas daerah Tulungagung. Sebagaimana daerahdaerah lain penghasil batik, Tulungagung dalam upaya menjaga tradisi juga masih menerapkan pemakaian batik berdasarkan motif yang disesuaikan dengan hajat maupun ritual yang akan dilaksanakan. Seperti diketahui, bahwa dalam batik (tradisional bukan modern) di dalamnya terkandung nilai transenden, terselip berbagai doa, dan nilai filosofis, dimana batik menjadi salah satu budaya visual yang memiliki wujud form follows myth, bukan sekadar form follows function.

Dalam siklus kehidupan manusia batik sudah mulai digunakan bahkan sebelum lahir, yaitu di masa kehamilan. Batik mulai digunakan pada upacara mitoni. Pada upacara mitoni ini terdapat beberapa tahap yang salah satunya adalah siraman dimana dalam tahap ini sang calon ibu yang mengandung akan di-sirami (dimandikan) sebanyak tujuh kali dengan tujuh kain batik yang brgantian. Siraman ini dilakukan oleh wanita yang memiliki posisi 'dituakan'. Adapun dalam prosesi ini terdapat tujuh macam motif batik yang biasanya digunakan, yaitu: (1) Motif Sido Mukti, motif ini digunakan karena memiliki makna kehidupan yang bahagian dan tentram; (2) Motif Sido Asih, motif ini digunakan karena memiliki makna kasih terhadap sesama manusia; (3) Motif Sido Luhur, dimana motif ini digunakan dengan harapan agar bayinya kelak hidup dalam kemuliaan. (4) Motif Wahyu Tumurun, dari penggunaan motif ini diharapkan sang anak nanti akan mendapatkan segala kebaikan dari Tuhan; (5) Motif Nagasari, motif ini digunakan dengan tujuan agar sang ibu memiliki kesuburan dan kemakmuran; (6) Motif Grompol, motif ini bertujuan agar segala jenis kebaikan dapat melekat pada sang anak; (7) Motif Semen Rama, motif ini memiliki makna kehidupan yang terus bersemi hingga sampai pada kemakmuran.

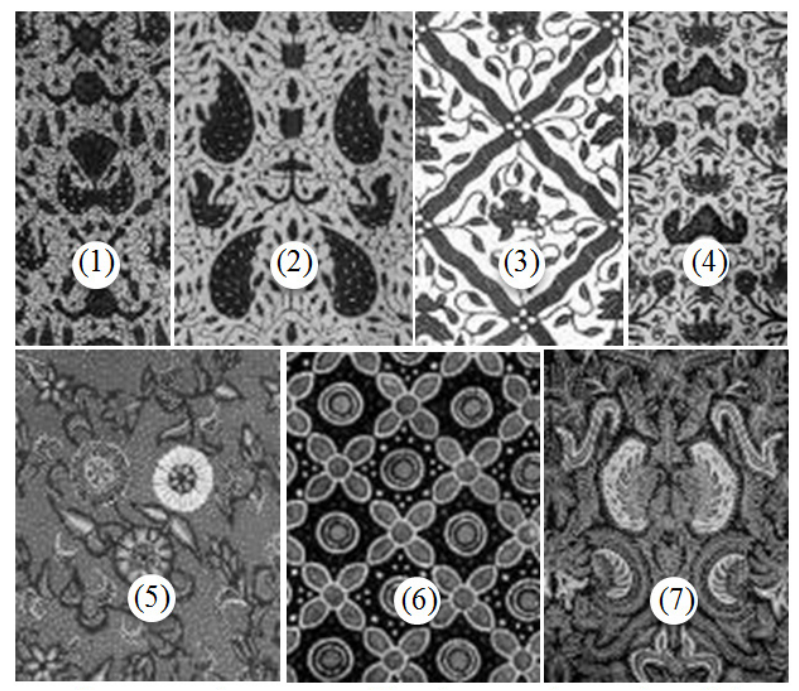

Gambar 1. Berbagai motif batik yang digunakan dalam prosesi mitoni.

(Sumber: infobatik.id, diakses 4 Oktober 2019) 
Kemudian pada tahap siklus selanjutnya Batik digunakan kembali pada tahap pernikahan. Pada tahap pernikahan sebenarnya masyarakat Tulungagung lebih berkiblat atau mengikuti adat Surakarta. Dalam prosesi pernikahan tradisi di masyarakat Tulungagung digunakan beberapa macam batik antara lain yaitu semen rante, semen berlatar putih, satria manah, dan sido mukti. Namun seiring perkembangan zaman batik yang digunakan berangsur berganti dan hanya tersisa motif sido mukti dan motif gadjah mada yang merupakan motif batik khas Tulungagung.

Motif Sido Mukti pada dasarnya merupakan wujud do'a dan harapan yang diwujudkan dalam bentuk ornamen dan isen-isen. Sido berarti Jadi dan Mukti berarti kebahagiaan, atau tidak kekurangan sesuatu apapun. Batik motif Sido Mukti memiliki ornamen utama gambar kupu-kupu. Kupu-kupu disini adalah pengambaran dari harapan indah yang mampu terbang tinggi, sama seperti binatang kupukupu itu sendiri. Dari bentuk dasar kupu-kupu ini kemudian juga distilisasi hingga berbentuk menyerupai singgasana. Gambar singgasana ini dimaksudkan bagi pemakai batik motif ini akan memiliki derajat atau penghormatan dari orang lainnya. Selaras dengan acara pernikahan dimana mempelai seringkali disebut sebagai raja dan ratu selama sehari. Ornamen lainnya adalah penggambaran gunung Meru, yang dgambarkan berwarna hitam. Meru menggambarkan kemegahan, keagungan. Sedangkan hitam dalam dalam batik Jawa sebenarnya merupakan warna biru yang sangat tua, memiliki arti kekuatan, kemewahan, sensualitas, misteri sekaligus keanggunan (Nurlaili M \& Hikmawati, 2018).

Lalu motif Gadjah Mada, adalah motif khas Tulungagung yang dikembangkan dari beberapa motif batik. Motif batik Gadjah Mada dibuat pertama kali pada kisaran tahun 1932. Dikutip dari laman infobatik.id (diakses 4 Oktober 2019, 21.37) motif batik ini merupakan hasil kreasi dari Haji Sapuan. Motif batik gadjah mada ini sendiri berdasar perkembangannya mencangkup beragam jenis motif dasar batik, sehingga terkesan lebih sebgai hasil penggabungan dari beberapa motif batik. Filosofi utama yang ingin disampaikan bahwa sesuai dengan namanya Gadjah Mada yaitu pemersatu Nusantara, motif batik ini juga merupakan kesatuan dari beraneka macam batik lainnya. Namun demikian masih terdapat batasan cangkupan dari motif ini. Motif gadjah mada memiliki ciri khas antara lain di dalamnya terdapat motif buketan (seperti ombak banyu atau sekar jagad). Lalu dari penggunaan warna motif ini biasanya menggunakan warna ungu (kebangkitan), hijau (ketentraman), hitam (kekuatan batin), biru (penyatu), dan coklat (tanah/asal muasal kehidupan).

Pada bagian terakhir yaitu siklus kematian, batik masih memiliki fungsi yang cukup penting dalam tradisi masyarakat Tulungagung. Ketika seseorang meninggal maka dalam prosesi sebelum pemakman maka digunakan kain yang dikenal dengan nama slobok. Kain yang digunakan biasanya adalah batik dengan motif Kawung Polos. Motif Kawung Polos ini melambangkan kembalinya manusia kembali ke alam asal (alam barzah). Motif Kawung secara visual terdiri dari gambar empat bulatan/oval yang ditata mengeli-lingi sebuah pusat dan dengan arah diagonal berlawanan ditata secara selang-seling. Gambar keempat oval ini merupakan penyederhanaan atau penggambaran secara ikonik dari buah kolang-kaling yang merupakan bagian (buah) dari pohon aren secara keseluruhan. Buah aren memiliki memiliki nilai filosofis bahwa terkadang kebaikan akan tidak begitu saja tampak, atau isi kolang kaling yang diibaratkan kebaikan, sering kali disembunyikan dengan kulit kerasnya agar tidak timbul rasa pamrih. Sedangkan pohon aren yang dapat berguna mulai dari daun hingga akar dapat diartikan bahwa pemakai batik motif kawung yang pada mulanya adalah para abdi dalem diharapkan memiliki 'rasa manembah' dan jiwa yang suci sehingga dapat berguna bagi sesama. Jadi maksud dari penggunaan motif ini pada siklus kematian adalah adanya harapan agar apa yang dilakukan orang yang meninggal semasa hidup dapat bermanfaat bagi yang telah ditinggalkan.

\section{Ritual Tradisi Slametan dalam Siklus}

Kehidupan Masyarakat Tulungagung dan Budaya Visual di dalamnya. Slametan atau Selamatan dikenal sebagai salah satu ritual hasidari akulturasi masyarakat Jawa dengan agama baru yang masuk seperti agama Hindu-Buddha dan agam Islam. Ritual ini sendiri secara lebih lanjut dapat disebut sebagai salah satu contoh wujud hasil dari sinkretisme. Masyarkat Jawa seperti dijelaskan di bagian pendahuluan telah mengalami pertemuan dengan berbagai masyarakat dari belahan dunia lain yang membawa budaya dan agama mereka masing-masing sehingga menghasilkan masyarakat Jawa yang plural hingga saat ini. Ritual Slametan juga mampu bertahan hingga saat ini tak lain 
karena adanya pluralitas di dalam masyarakat Jawa. Di Tulungagung secara khusus dan bagi masyarakat Jawa secara umum Slametan bisa dikatakan sebagai ritual inti dari Islam Kejawen (atau seringkali di identikkan sebagai kegiatan Islam Abangan dalam pengertian luas), meskipun pada faktanya kini Slametan juga sudah mulai bertransformasi menjadi lebih 'Islami' agar dapat dijangkau dan dilakukan oleh mereka Islam Putihan.

Sebelumnya Slametan dikatakan sebagai ritual ini. Hal ini berdasarkan kebiasaan masyarakat Jawa yang melakukan ritual Slametan hampir di tiap momen yang dianggap penting sebagai sarana memohon kepada Tuhan Yang Maha Esa. Masyarakat Jawa secara umum diketahui telah memiliki 'agama' sendiri bahkan sebelum agama lain seperti Hindhu-Buddha, Islam, Kristen, dan lain-lain masuk. Agama ini disebut sebagai agama Kapitayan yang dalam ajaran ini penganutnya menyembah Sang Hyang Taya (Tuhan yang berarti Yang Maha Kosong atau Tak Berwujud). Oleh para orang Barat kemudian ajaran inilah yang dianggap dan disebut sebagai kepercayaan Animisme dan Dinamisme. Dari latar belakang sejarah yang panjang dari sistem keagamaan masyarakat Jawa, Slametan dapat dilihat sebagai wujud dari kepercayaan yang sangat kuat dan wujud rasa selalu bersyukur dari masyarakat Jawa. Jadi singkatnya ritual Slametan merupakan sarana untuk bersyukur dan memohon atas keselamatan kepada Tuhan oleh para pelakunya.

Slametan yang ada di Tulungagung sebagaimana ritual lain yang ada di dalam tradisi masyarakat Jawa maupun lainnya di dalam pelaksanaannya juga menganut pada prosesi yang sudah ada semenjak dulu dan menggunakan berbagai 'perangkat' di dalam pelaksanaannya. Di dalam istilah Jawa 'perangkat' inti yang digunakan dalam ritual Slametan disebut dengan Cok Bakal. Cok Bakal yang memiliki arti 'cikal bakal' atau 'asal muasal', dapat dikatakan sebagai komponen paling penting dalam rangka dilaksanakannya ritual Slametan, lebih penting dari 'perangkat' (sesaji) lainnya. Cok Bakal sendiri dapat dikategorikan sebagai budaya visual karena di dalamnya juga telah disisipkan berbagai nilai, ide, serta gagasan. Dari wawancara yang dilakukan penulis dengan narasumber Santoso (2019) Cok Bakal yang merupakan piranti utama dalam slametan terdiri dari beberapa bahan yaitu antara lain: Kolo Gumantung : isi kelapa, merica, ketumbar, dan kemiri. Kolo Kependhem : kunir, kunyit, bawang merah, dan bawang putih. Bumbon: garam dan gula merah.
Kinangan: daun sirih, kapur sirih, dan gambir

Semua bahan yang disebutkan diatas lalu dimasukkan ke dalam wadah serupa mangkuk yang dibuat dari daun pisan yang disebut dengan Takir. Wadah ini secara visual menggambarkan bahwa apa yang perlu 'diwadahi' atau disimpan adalah hal-hal yang sebelumnya benar-benar telah dipilih secara matang. Masyarakat Jawa selain memliki kebiasaan menciptakan budaya visual, juga memiliki kebiasanya menyisipkan 'arti' dalam sebuah nama dalam bentuk akronim. Takir dalam bahasa Jawa sendiri secara akronim merupakan kependekan dari wes tatag lan dipikir (sudah mantab dan dipikirkan). Takir kemudian di segel atau di tutup menggunakan lidi (bithing sodo) yang sudah tua. Lidi secara visual dianggap menggambarkan kemauan yang lurus dan keteguhan hati. Lidi digunakan untuk mengunci Takir karena setiap pilihan yang diambil harus ditetapkan (dikunci) dengan keteguhan hati. Secara lebih jelas maksudnya ketika akan dilakukan Slametan maka apa yang di doakan, apa yang akan dimintakan kepada Tuhan, harus dipikirkan dulu secara matang, lalu dimantabkan dalam hati, kemudian dimintakan dengan khusyuk serta hati yang lurus.

Seperti halnya dalam pemaparan pada sub bagian batik diatas. Agar lebih mudah penulis membagi macam ritual tradisi dalam siklus kehiduan menjadi tiga kategori berdasarkan rentang waktu yaitu sebelum dan sesudah melahirkan hingga masa anak-anak, masa remaja hingga dewasa, dan masa setelah kehidupan (kematian).

\section{Masa sebelum dan sesudah melahirkan}

Pada fase ini dalam tradisi masyarakat Tulungagung ritual pertama yang dilakukan adalah ketika usia kehamilan 7 bulan. Selain dilakukan prosesi siraman menggunakan 7 macam batik seperti yang dijelaskan diatas, dalam acara 7 bulanan atau nyambung tuwuh ini juga terdapat beberapa 'perangkat' lain yang digunakan. Yang pertama adalah cengkir gading, sepasang kelapa gading dengan gambar wayang Kamajaya dan Kamaratih. Penggambaran kedua tokoh ini diharapkan nanti ketika bayi lahir apabila laki-laki akan setampan Kamajaya (Arjuna) dan apabila perempuan akan secantik Kamaratih (Sembadra). Selain itu cengkir gading dibuat sepasang dengan harapan ketika sampai pada masa dewasa dan menikah harapannya dapat memiliki kisah cinta langgeng seperti Arjuna dan Sembadra. 
Dalam penggunaannya cengkir gading ini digunakan dalam acara brojolan, bagian dari prosesi 7 bulanan. Dalam acara brojolan calon ibu memakai jarik yang dilonggarkan yang disertai tali, kemudian nenek calon bayi ini memasukkan cengkir gading melalui kain batik yang dikenakan calon ibu lalu menangkap kelapa yang jatuh dan memberikannya kepada calon ayah, setelah itu sang ayah memotong tali sebagai perumpamaan atau pertanda memotong halangan dan rintangan. Cengkir gading juga merupakan hasil dari 'kerata basa', yaitu pemaknaan lain dari sebuah kata atau kalimat. Cengkir dapat diartikan 'kencenge pikir' yang berarti bulatnya tekad, atau teguhnya pendirian.

Selain cengkir gading dalam prosesi 7 bulanan juga dibuat jenang procot atau jenang sungsum. Jenang sungsum yang memiliki wujud halus dan bertekstur lembut merupakan penggambaran harapan agar ketika proses persalinan akan berjalan lancar (dalam istilah Jawa disebut gangsar).

Ketika bayi lahir kemudian dilakukan ritual yang disebut dengan brokohan. Pada ritual ini ketika bayi lahir dan terlepas ari-arinya, maka ari-ari tersebut dibungkus menggunakan kain putih (biasanya mori) bersamaan dengan beberapa benda tergantung dari harapan kedua orang tua. Misalnya ketika orang tua ingin anaknya shalih atau shalihah maka ari-ari akan dikubur bersamaan dengan buku Yasin kecil. Atau ketika orang tua berharap anaknya menjadi pandai, maka ari-ari akan dikubur dengan buku tulis dan pensil.

Pada usia bayi 36 hari dilakukan upacara Selapanan. Dalam prosesinya diperlukan ubo rampen berupa buceng kuat, dan jenang sengkala. Buceng kuat (dalam Baihaqi, 2018) adalah semacam hidangan yang terdiri dari 7 komponen, yaitu beras ketan yang dibentuk mengerucut menyerupai tumpeng; nasi golong atau nasi yang dikepal sebesar bola tenis; ayam ingkung jago atau jantan; urap-urap berupa kacang panjang, kangkung, kecambah dan diberi parutan kelapa. Dari komponen-kompenen yang telah disebutkan memiliki makna-makna tersendiri. Wujud nasi yang mengerucut bermakna kefokusan dalam mencapai tujuan; nasi golong merupakan penggambaran dari bulatnya tekad seseorang; ayam ingkung menggunakan ayam jago sebagai perlambang dari kebajikan dalam perbuatan; lalu urap-urap merupakan penggambaran keanekaragaman manusia yang tetap memiliki satu tugas yang sama yaitu sebagai kawula atau hamba kepada Tuhan Yang Maha Esa. Buceng kuat dalam namanya juga memiliki 'kerata basa' yang demikian 'buceng' berarti 'nyebut sing kenceng' atau artinya 'menyebut' Nama-Nya tanpa henti.

Pada usia bayi 7 bulan kemudian di masyarakat Tulungagung diadakan tradisi mitoni (7 bulanan) yang dilakukan berbarengan dengan tedhak siten (upacara menapak tanah pertama kali). Di dalam ritual ini terdapat 4 perangkat yang digunakan, yaitu jadah 7 rupa, tangga dari tebu wulung, kurungan ayam yang dihiasi, dan udik-udik. Menurut Patonah (2019) Jadah yang memliki tekstur ulet diibaratkan seperti hidup yang membutuhkan keuletan untuk menjalaninya. Sedangkan jadah yang 7 rupa merupakan penggambaran dari kehidupan yang dialami oleh bayi, jadah putih memiliki arti kesucian, jadah merah berarti keberanian, jadah merahmuda berarti kelembutan hati, jadah hijau berarti kehidupan yang damai, jadah kuning berarti bersinarnya kehidupan, jadah ungu berarti keluhuran budi, dan terakhir jadah hitam berarti keabadian.

Tangga dari tebu wulung digambarkan merupakan berbagai tingkatan yang perlu dilalui oleh sang anak kelak. Biasanya ketika menaiki tangga ini bayi seringkali diibaratkan sedang menjalani berbagai tingkatan pendidikan (dari TK hingga Perguruan Tinggi). Penggunaan tebu wulung sendiri juga tidak lepas dari karakteristik visual tebu wulung yang berwarna hitam perlambang keteguhan. Tebu juga memiliki 'kerata basa' yaitu tebu diartikan sebagai antebing kalbu yang artinya teguhnya hati.

Kurungan ayam dalam ritual mitoni ini biasana di beri beraneka ragam hiasan dibagian luar. Ketika prosesi mitoni bayi akan ditempatkan di dalam kurungan. Hal ini dilakukan sebgai penggambaran bahwa kelak bayi diharakan tidak akan mudah tergoda oleh hal-hal duniawi. Dalam prosesi ini ketika berada di dalam kurungan bayi juga akan diberi potongan dari ayam ingkung sebagai sebagai penggambaran perlawanan terhadap godaan dunia dengan tindak kebijakan.

Udik-udik yaitu beras kuning mentah yang biasanya dicampur dengan empon-empon, uang koin, serta bunga mawar dan melati. Udik-udik biasanya dibagikan dengandisebar lalu anak-anak yang mengikuti upacara mitoni ini akan berebut uang koin yang disebar. Udik-udik ini merupakan perlambangan bahwa kelak ketika ana tumbuh menjadi seseorang yang suka menolong dan tidak segan berbagi materi kepada orang lain. 


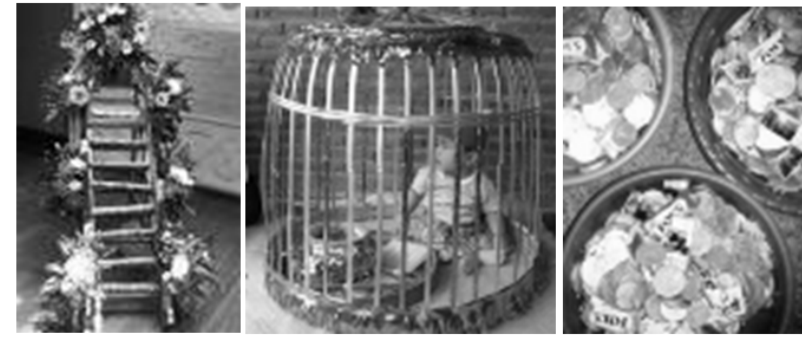

Gambar 2. Perlengkapan upacara pitonan. (Dari kirikanan, tangga, kurungan, udik-udik).

(Sumber: hipwee.com, diakses 7 Oktober 2019)

\section{Masa remaja hingga dewasa}

Di rentang masa ini prosesi yang dianggap penting dan mayoritas masih dijalankan hingga saat ini adalah tradisi pernikahan adat. Pada pernikahan ini sebenarnya terdapat banyak sekali budaya visual di dalamnya. Pada prosesi ini berbagai budaya visual terwujud mulai dari kostum atau pakaian adat (termasuk batik) yang dikenakan, riasan pengantin, hingga berbagai komponen kecil yang digunakan dalam prosesi ritual ini. Beberapa budaya visual yang digunakan dalam rangkaian prosesi pernikahan antara lain, yaitu riasan (paes) yang digunakan pengantin perempuan, kembar mayang, cengkir gading, daun sirih dalam balangan gantal, setandan pisang raja, janur kuning, hingga berbagai perangkat dan sesajen lainnya.

Menurut Widayanti (2011) ketika disebut paes maka kata paes disini akan merujuk lebih spesifik kepada tata rias yang ada pada dahi mempelai perempuan dan tata rambut yang digunakannya. Dalam prosesi pernikahan riasan paes mengusung banyak makna di dalamnya. Paes sendiri terdiri dari 8 bagian yang semuanya dimaksudkan bagi penggunanya. Berikut penjelasan dari bagian-bagian yang ada pada paes: 1) Penunggul yaitu bagian tengah dahi yang berarti keunggulan, dan yang paling baik; 2 ) Wanda Luruh yaitu bentuk yang arahnya melengkung kebawah, yaitu bermakna bahwa sifat lembut dan 'menunduk' berbudi luhur; 3) Pengapit adalah hiasan yang mengapit penunggul, memiliki makna bagian kiri sebagai godaan sedangkan bagian kanan sebagai pemomong atau pengasuh agar teguh imannya; 4) Penitis adalah hiasan yang terletak diatas godheg, maknanya adalah kearifan yang akan membawa pengantin mancapai tujuab baik yang diharapkan; 5) Godheg yaitu hiasan pada cambang yang bentuknya melengkung ke belakang, maknanya asal-usul manusia dan bagaimana manusia akan kembali, meninggalkan hal duniawi; 6) Prada dan Ketep adalah pinggiran paes yang biasanya berwarna emas, memiliki makna keagungan; 7) Kinjengan, hiasan berbentuk seperti capung yang bermakna keuletan dalam hidup; 8) Cithak yaitu hiatas belahketupat keci yanh ada di dahi, memiliki makna makna perlindungan dari hal yang buruk. Cithak ditempatkan di pusat indra karena adanya kepercayaan bahwa ketika pusat indra lemah, maka

Lalu pada prosesi pernikahan adat di Jawa di Tulungagung, juga terdapat hiasan-hiasan yang juga memiliki berbagai makna. Pada hari temu manten biasanya terdapat hiasan berupa 2 buah tandan pisang raja, yang buah pisang ini dianggap sebagai penggambaran suami yang akan menjadi kepala rumah tangga harapannya akan mampu membimbing keluarganya dalam kebaikan dimanapun mereka berada. Lalu Tebu Wulung (merah) biasanya diletakkan di tiang pintu masuk sebagi perlambang antebing kalbu atau kemantaban hati mereka yang menggelar pernikahan. Cengkir gading dalam prosesi pernikahan hampir serupa dengan apa yang ada di prosesi 7 bulanan kehamilan, yaitu sebaga harapan untuk kelanggengan suami istri. Janur kuning yang dipasang biasanya di depan lokasi pernikahan memiliki makna 'sejane ning nur' yang artinya arah menggapai cahaya ilahi. Maksudnya pernikahan yang dilakukan adalah salah satu upaya untuk mencapai kesempurnaan dan ridho Tuhan Yang Maha Kuasa.

Pada upacara temu manten terdapat salah satu hiasan yang dianggap juga sangat penting yaitu kembar mayang. Hiasan ini dinilai memiliki makna yang sangat besar dibalik bentuknya yang elok. Menurut Widayanti (2008) kembar mayang di definisikan sebagai hiasan yang populer digunakan dalam pernikahan berupa rangkaian janur, bunga berbentuk seperti merak, dan dedaunan yang dirangkai pada batang pisang. Menurut Kristanto (2019) kembar mayang pasangan manusia yang siap secara lahir dan batin untuk menyemai bibit (keturunan) berikutnya. Kembar mayang berbentuk seperti gunung memilki makna bahwa pria harus memiliki sifat agung, banyak pengetahuan serta pengalaman, dan penuh kesabaran. Pada kembar mayang terdapat hiasan menyerupai keris yang maknanya bahwa mempelai harus selalu berhatihati, bersikap bijak dan pandai dalam bertindak, seolah menggunakan senjata. Kemudian hiasan seperti cambuk maksudnya agar mempelai tidak mudah putus asa ketika menemui masalah. Hiasan 
menyerupai payung memiliki makna perlindungan bagi kedua mempelai, dan hiasan berbentuk burung sebagai perlambang motivasi tinggi dalam menjalani kehidupan.

Pada hiasan kembar mayang juga terdapat kelangkapan berupa bermacam-macam dedaunan yang masing-masing memiliki makna. Daun beringin memiliki makna perlindungan bagi keluarga, daun dadap srep bermakna kejernihan berfikir dan kerenangan dalam menghadai berbagai cobaan, dlingo bengle yang juga bermakna melindungi dari gangguan roh jahat. Dalam pengertian lain bermacam dedaunan ini juga memiliki makna kelengkapan, sehingga harapannya ketika menjalani kehidupan berumah tangga tidak akan menemui kekurangan.

\section{Masa kematian dan setelahnya}

Pada fase hidup ini budaya visual pertama diterapkan ketika seseorang tutup usia. Ketika seseorang meninggal maka akan dilakukan serangkaian prosesi pada hari itu juga. Seperti pada fase hidup sebelumnya pada fase ini budaya visual masih lekat dengan pemaknaan. Pada saat dilakukan prosesi mengurus layon (jenazah) maka akan terdapat beberapa perangkat yang masing-masing memiliki makna tersendiri.

Adapun perangkat yang pertama adalah daun kelor atau dhadhap srep, daun ini dalam kebudayaan Jawa di narasian mampu untuk melunturkan hal-hal yang sifatnya metafisik. Dalam prosesi mengurus layon ini daun kelor bertujuan untuk menghilangkan (mengurangi) dosa-dosa selama masih hidup di dunia, sedangkan daun dhadhap srep merupakan simbol ketentraman dan kedamaian agar lebih mudah berpulang kepada Tuhan.

Perangkat lainnya ada kelapa muda yang diambil airnya merpakan perlambangan dari air suci, jadi kelapa disini dapat dimaknai sebagai harapan agar layon mendapat kesucian kembali sebelum sampai kepangkuan Tuhan. Kemudian ada payung yang digunakan untuk memayungi layon. Payung ini dapat dimaknai sebagai pemberian kasih sayang dari mereka yang masih hidup kepada yang telah meninggal. Payung juga diartikan sebagai perlindungan dalam perjalanan dari dunia menuju akhirat. Selanjutnya kembang setaman, yang digunakan sebagai wujud penghormatan bagi yang telah meninggal. Selain itu kembang setaman juga dapat dimaknai sebagai wujud dari setiap kebaikan yang diperbuat oleh orang yang meninggal. Dalam prosesi hari pertama ini pula dibuat buceng pungkur, yaitu berupa semacam tumpeng yang dibelah menjadi dua secara vertikal lalu dibalik hadapnya sehingga saling membelakangi. Dalam istilah Jawa dikenal sebagai ungkur-ungkuran, perlambang manusia yang berjalan kedepan membelakangi dunia fana, dunia kehidupan. Buceng pungkur biasanya dibuat dengan nasi putih dengan tambahan minimalis guna menggambarkan bahwa ketika sesorang meninggal maka akan meninggalkan hal-hal gemerlap yang sifatnya duniawi.

Setelah sesorang meninggal akan dilakukan beberapa kali upacara. Pertama adalah upacara ngesur tanah (geblag). Ngesur tanah berarti menggeser tanah atau membuat liang lahat. Lalu ada selamatan pada tiap hari ganjil setelah kematian (3, 5, 7 harian), selamatan 40 harian, mendhak pertama, mendhak kedua, mendhak ketiga atau seribu harian. Menurut Kristanto (2019) dari upacara-upacara yang dilakukan biasanya terdapat sesaji berupa ayam atau ingkung, sebagai perlambang pengembalian hal fisik (kulit, darah, dan tulang) hingga semuanya lenyap pada upacara mendhak ketiga atau seribu harian.

\section{Langkah Menjaga Warisan Budaya Visual}

Diawal penelitian ini telah dijelaskan bahwa masyarakat Jawa hingga hari ini mayoritas telah menjadi pribadi yang seringkali melanjutkan warisan kebudayaan sebagai 'something taken for granted'. Hal ini yang menjadikan minimnya pengetahuan akan budaya yang dimiliki sendiri. Kebiasaan masyarakat Jawa yang lebih dominan mewariskan sesuatu sebagai yang dituturkan, dan penanaman pemahaman yang biasanya dilakukan oleh orang, tentang batasan pengetahuan seperti konsep 'tidak pantas', kualat, tabu, pamali, dan lain sebagainya. Memang tujuan sebenarnya agar sebuah budaya tertib dijalankan tanpa ada penyelewengan. Namun lambat laun akan mengikis pengetahuan, termasuk tentang esensi apa yang dilakukan dalam bentuk budaya.

Pada masyarakat Jawa di Tulungagung pengikisan kebudayaan semacam ini dapat dilihat bagaimana mereka yang sebenarnya menganut atau berkiblat pada kebudayaan Mataraman, termasuk pula berbagai berbagai ritual tradisi seperti pada siklus hidup beserta berbagai budaya visual di dalamnya. Namun dewasa ini beragai penyesuaian dilakukan sehingga lambat laun budaya Mataraman mulai ditinggalkan. Seperti pada rangkaian ritual dalam siklus kehidupan sudah tidak 
dilakukan secara runtut. Sebut saja pada bulan-bulan kehamilan, kini mayoritas masyarakat Tulungagung hanya melakukan upacara tradisi mitoni. Padalah semula ada upacara ditiap bulan mulai dua bulan masa kehamilan (ngloroni, neloni, ngapati, mglimani, sampai nyangani).

Hingga dewasa ini dalam konteks kemajuan zaman telah ditawarkan berbagai metode guna menjaga (merevitalisasi) suatu kebudayaan. Beberapa contoh diantaranya adalah yang dapat dikatakan lazim dalam penelitian untuk merevitalisasi sebuah kebudayaan, seperti Participatory Action Research, Artistic Research, Etnografi, dan salah satu yang terbaru adalah metode Atumics (2012) yang di perkenalkan dan di kembangkan oleh Dr. Adhi Nugraha, M.A.

Dalam metode Atumics ini dikatakan bahwa sebuah kebudayaan memiliki 6 elemen fundamental, yaitu Artefak, Teknik, Utilitas, Material, Concept (konsep), dan Shape (bentuk) (Nugraha, 2018). Keenam elemen tersebut dianggap sebagai modal yang nanti dapat digunakan untuk mengembangkan karya berbasis kenusantaraan (sekaligus bertujuan revitalisasi). Metode Atumics dilakukan dengan langkah pertama yaitu identifikasi elemen mana yang dianggap memiliki potensi paling baik untuk dikembangkan. Elemen yang dimaksud bisa berupa unsur ornamen, bahan atau teknik produksi. Langkah selanjutnya adalah eksplorasi unsur kekinian yang dinilai baik dan tidak merusak unsur tradisi yang dipilih sebelumnya. Lalu langkah terakhir adalah penyatuan antara elemen Atumics tradisi dengan elemen Atumics Modern sehingga diperoleh produk baru, yang dalam hal ini biasanya berbentuk material atau budaya visual.

Proses penyilangan semacam yang ada pada metode Atumics ini adalah salah satu yang paling banyak dilakukan oleh masyarakat luas dewasa ini dengan motif pelestarian kebudayaan.

\section{Simpulan}

Masyarakat Jawa khusunya di masyarakat Tulungagung hingga hari ini menjalankan kebudayaan hasil dari berbagai persilangan budaya yang telah terjadi dimasa lalu. Persilangan ini kemudian menghasilkan perkembangan budaya yang beberapa masih hidup dan bertahan hingga saat ini. Salah satu budaya yang dimaksud adalah budaya visual seperti yang telah dijelaskan diatas. Masyarakat Tulungagung yang mayoritas merupakan pelaku kebudayaan Jawa dalam rangkaian siklus kehidupannya melakukan berbagai ritual tradisi yang erat kaitannya dengan budaya visual. Dalam budaya visual ini terkandung berbagai ide, gagasan, harapan serta doa. Budaya visual yang ada hingga saat ini juga dapat digunakan sebagai bukti bahwa masyarakat Jawa di masa lalu telah sampai pada aktualisasi diri, bukti bahwa mereka adalah masyarakat kreatif.

Dalam pemaparan diatas telah dijelaskan berbagai macam budaya visual yang hingga hari ini, meskipun terus memudar, masih berlangsung dan digunakan oleh masyarakat Jawa di Tulungagung. Budaya visual memiliki berbagai fungsi melihat dari cara penerapannya seperti mewakili pribadi dalam menciptakan pengharapan, sebagai sarana representasi diri, hingga sebagai sarana 'berkomunikasi' dengan sang pencipta. Dengan diadakannya penelitian ini diharapakan masyarakat yang biasanya menggunakan budaya sebagai 'something taken for granted' akan mendapatkan wawasan lebih tentang budaya yang dijalankannya, sehingga tidak sampai kehilangan esensi dari budaya itu sendiri. Dengan bertambahnya wawasan mendasar tentang budaya visual yang ada, maka peluang pengembangan dalam rangka revitalisasi budaya akan lebih mungkin terjadi dengan semakin minimnya pengikisan dari esensi budaya yang dikembangkan. Selain itu melalui pemahaman akan budaya visual tradisi maka hal ini dapat dijadikan aset atau modal kreatif guna melestarikan kebudayaan yang kebaruan dengan mengusung tradisi sebagai identitas.

\section{Daftar Pustaka}

Astrini, Retno Andini. (2019). Perancangan video profil khasanah Batik "Adi Purwo" Kabupaten Purworejo. ARS : Jurnal Seni Rupa \& Desain. Volume 21 (No. 1), 33-43.

Dimyati. (2003). Perbedaan Orientasi Tujuan Berprestasi Belajar Pendidikan Jasmani Antara Siswa Etnis Jawa Dan Etnis Tionghoa. Jurnal Psikologika. Diunduh 28 September 2019 dari http://library.um.ac.id/free-contents/printbook2.php/koleksi-digital-perpustakaan-31040.html

Handayani, Wuri. Emilda, Nia. (2018). Pedagogi Estetik Berbasis Kearifan Lokal melalui Kriya Nusantara Batik Cianjur. JOUSA : Journal of Urban Society's Arts. Volume 5 (No. 2), 5965. 
Koentjaraningrat. (1993). Kebudayaan, Mentalitas dan Pembangunan. Gramedia Pustaka Utama, Jakarta.

Nugraha, Adhi. (2018). Transforming Tradition in Indonesia. Design Roots: Culturally Significant Designs, Products, and Practices. Bloomsbury Publications, London.

Nurlaili M, Siti. Hikmawati, Ari. (2018). Motif Batik Tradisional Surakarta Tinjauan Makna Filosofis dan Nilai-nilai Islam. Jurnal Al-Ulum IAIN Sunan Amai Gorontalo. Diunduh 29 November 2019 dari https://media.neliti. $\mathrm{com} / \mathrm{media} / \mathrm{publications} / 276940$-none3e130754.pdf

Sachari, Agus. (2007). Budaya Visual Indonesia. Erlangga, Jakarta.

Widayanti, Sri. (2008). Makna Filosofis Kembar Mayang Dalam Kehidupan Masyarakat Jawa. Jurnal Filsafat Universitas Gadjah Mada. Diunduh 28 November 2019 dari https://media.neliti.com/media/publications/83917-IDmakna-filosofis-kembar-mayang-dalam-kehi. pdf

Widayanti, Sri. (2011). Tinjauan Filsafat Seniterhadap Tata Rias Dan Busana Pengantinpaes Ageng Kanigaran Gaya Yogyakarta. Jurnal Filsafat Universitas Gadjah Mada. Diunduh 28 November 2019 dari https://media.neliti.com/media/ publications/85852-ID-tinjauan-filsafat-seniterhadap-tata-ria.pdf.

\section{Daftar Sumber Online}

https://kumparan.com/kumparanstyle/ lahir-dan-mati-dalam-buaian-batik/Baihaqi, Mochammad Chafidz. (22 November 2018).

ht tps://blog.iaintulungagung.ac.id/ pkij/2018/11/22/sakralitas-buceng-kuat/

https://budaya-indonesia.org/Batik-Gajah-MadaTulungagung/

\section{Daftar Nara Sumber/Informan}

Patonah (49th.), ibu rumah tangga, wawancara tanggal 27September2019 di rumahnya, Mirigambar, Sumbergempol, Tulungagung.

Santoso (57th.), Seniman kriya dan budayawan, wawancara tanggal 21 September 2019 di rumahnya, Mirigambar, Sumbergempol, Tulungagung.

Zuly Kristanto(29th.), Sastrawan dan budayawan, wawancara tanggal 27 September 2019 di rumahnya, Mirigambar, Sumbergempol, Tulungagung. 